\title{
A MICROSTRATIGRAPHIC INVESTIGATION INTO THE LONGEVITY OF ARCHAEOLOGICAL RESIDUES, STERKFONTEIN, SOUTH AFRICA
}

\author{
Peta Jane Jones \\ School of Social Science \\ The University of Queensland \\ St Lucia QLD 4072 Australia
}

\begin{abstract}
Controversial claims that proteinaceous residues have been detected on two-million-year-old stone tools from the stratigraphic unit Member five (M5) of the Sterkfontein site, South Africa, are examined through analysis of the microstratigraphy of M5's cemented breccia infill. This study was undertaken to determine the composition of the burial matrix and to understand the post-depositional processes at the site, as a means of examining the feasibility of proteinaceous residue preservation. Petrographic analysis of the samples revealed the main constituents of the M5 breccia to be calcite and clay. Two calcite structural types were observed, which may indicate two or more phases of cementation through calcification. The clay minerals appear to have bonded with the residues to create a fixed and stable environment. Chemical experiments found the M5 breccia had a relatively high potential for cation exchange and both rock types (breccia and dolomitic bedrock) were basic.
\end{abstract}

\section{KEYWORDS}

proteinaceous archaeological residues, clay, calcite, Sterkfontein

\section{INTRODUCTION}

Archaeological residues are microscopic remains of prehistoric lifeways, preserving minute traces of plants (such as cellulosic matter, starch and pollen) and animals (such as blood, plasma, feathers and bone) over considerable time periods (Briuer 1976; Dominguez-Rodrigo et al. 2001; Fullagar 2006; Fullagar and Field 1997; Fullagar and Jones 2004; Fullager et al. 1996; Fullagar et al. 2006; Garling 1998; Gerlach et al. 1996; Hardy 2004; Hardy and Rogers 2001; Hardy et al. 1997; Haslam 2003; Hyland et al. 1990; Kooyman et al. 1992; Loy 1983, 1998; Loy and Dixon 1998; Loy and Hardy 1992; Newman and Julig 1989; Richards 1989; Shanks et al. 2005; Tuross and Dillehay 1995; Williamson 1997). Residue recovery is a major addition to archaeological investigation, allowing for another level of inference: 'The ability to identify residues on stone artefacts will allow researchers to link tool use with animal species to support inferences about human cultural practices' (Shanks et al. 2005:36).

In late 1997, Loy claimed the detection of blood residues on Oldowan stone tools from the Sterkfontein cave site in the Republic of South Africa (Loy 1998). The stratigraphic unit from which the stone tools were recovered, the Oldowan Infill from Member 5 (M5), has been dated to approximately two million years (Kuman and Clarke 2000). The potential validation of 
these claims would demonstrate remarkable post-depositional survival of these organic residues (Figure 1) over a multi-million-year timeframe, regardless of the pre-burial factors that lead to the introduction of the residues to the tools.

From burial to excavation archaeological material is part of the taphonomic system, which includes all processes acting upon the materials in situ (Hanson 1980:157). The archaeological environment involves complex interactions between soil organic matter, soil micro-organisms and soil structure and properties (Haslam 2004:1718). Initial degradation of organic material is rapid, before it plateaus out and stabilises, leaving low molecular weight fragments which have the potential to form durable residues (Haslam 2004; Kimura et al. 2001; Sensabaugh et al. 1971a; see also Barton this volume). A small number of studies report that preservation of residues over significant timeframes is unlikely (Eisele et al. 1995; Tuross et al. 1996). However, the majority of investigations indicate that proteinaceous residues retain sufficient structure through time and in varying environmental and depositional conditions to allow for analysis (Cattaneo et al. 1990, 1993; Gurfinkel and Franklin 1988; Hyland et al. 1990; Loy 1983; Sensabaugh et al. 1971a, 1971b).

Physical, biochemical and molecular interactions have the potential to affect blood residue preservation (Brown 1988; Craig and Collins 2000; Heydari 2007; Wadley et al. 2004). The preburial processes that occur in the biostratinomic interval and contribute to residue preservation involve a complex interplay of the amount of blood deposited, UV exposure time and drying conditions of the blood residues (which allow the air to reduce the oxygenated blood to a more stable condition) (Cattaneo et al. 1993; Hortolà 2002; Loy 1983; Tuross et al. 1996). The cultural use of a tool in its systemic context may also contribute to blood residue preservation (Cattaneo et al. 1993; Hardy and Rogers 2001; Hortolà 1992; Shanks et al. 2001). For example, tool use can create minute indentations, such as microcracks, on an artefact's surface that can sequester ancient biological residues away from degradational conditions (Cattaneo et al. 1993; Newman and Julig 1989; Shanks et al. 1999, 2001, 2005; Tuross and Dillehay 1995).

Archaeological site formation processes (Enloe 2006; Heydari 2007; Latham and Herries 2004; Morin 2006; Piló et al. 2005; Rick et al. 2006; Schiffer 1996; Ward et al. 2006;) and diagenetic conditions of the host site are primary controls on residue survival. A stable soil matrix protects residues from percolating rainwater and chemical, physical, and biological processes (Cattaneo, et al. 1993; Kimura et al. 2001; Loy 1983). Alkaline soils favour residue recoverability as low $\mathrm{pH}$ may deprotonate basic functional groups that displace positively charged residues from the surface. Additionally, Loy (1987) highlighted the potential significance of high clay/silt content, which can contribute to stabilisation of proteinaceous residues.

Interactions between the dynamic depositional, burial and diagenetic processes that affect an archaeological site produce a highly specific set of conditions. Therefore, understanding the reasons for the preservation of residues on stone tools is beyond the scope of experimental studies (for example Wadley et al. 2004), which cannot sufficiently replicate these processes or the timeframes over which they occur. In contrast, the rocks that comprise the site preserve a signature of these processes, providing a record of site conditions. Determining the potential preservation mechanisms of the Sterkfontein blood residues requires a taphonomic investigation of the geological processes affecting site formation and how these create and affect the microenvironment of the cultural deposits.

This study reports a microstratigraphic investigation into the M5 geological matrix that enveloped the stone tools on which Loy's (1998) purported blood residues were detected, focusing on the key elements that may be conducive to residue preservation. This includes defining the composition of the burial matrix through petrogaphic analysis and determining cation exchange capacity (CEC) and $\mathrm{pH}$. From this study the depositional and post-depositional processes that affected M5 can be identified to better constrain the processes that might lead to ancient residue preservation, and therefore provides a basis for conducting future research. 


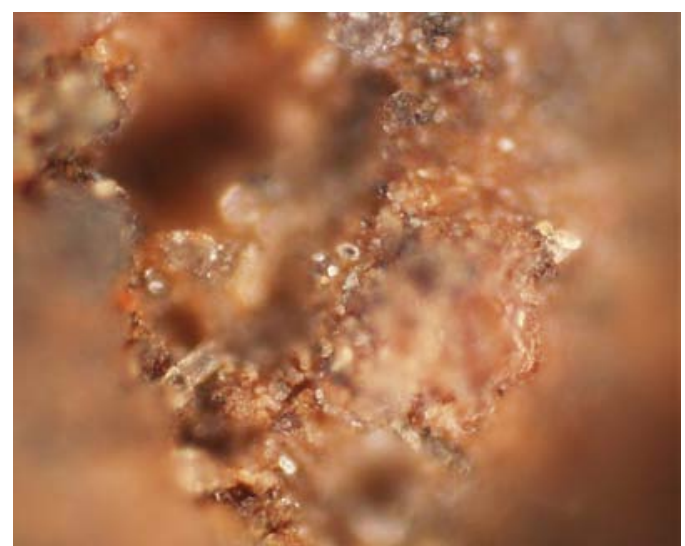

Figure 1. Proteinaceous blood residues found on M5 Oldowan stone tool no. StK2580 mag. 50x (micrograph and interpretation courtesy of Paul Kajewski, University of Queensland).

\section{THE STERKFONTEIN SITE}

The Sterkfontein site is situated within the republic of South Africa (Figure 2), $60 \mathrm{~km}$ northwest of Johannesburg near Krugersdorp, in the Gauteng region. The region is 1000 to $1800 \mathrm{~m}$ above sea level and is covered with grassland similar to savannah, with undulating hills, scattered trees and bushes. The geomorphic setting describes Sterkfontein as a small hill $(1491 \mathrm{~m})$, with cave entrances on top, approximately $45 \mathrm{~m}$ above a valley that supports the northeasterly flowing Blauuwbank River (Martini et al. 2004). The Blauuwbank River is situated $500 \mathrm{~m}$ downhill from the Sterkfontein deposits, and has its source in the Witswatersrand mountain range southwest of the Sterkfontein site. The rainy season occurs between October and April, maintaining green eastern lowlands and grasslands on the higher plateau regions of the Highveld and Bushveld. Evidence for this seasonal rain is recorded in the palaeoenvironmental data from Sterkfontein (Vrba 1975).

The Sterkfontein caves are part of a limestone karst deposit comprising several large connecting caves carved out of the Malmani dolomite of the Transvaal sequence (SACS 1980). The dolomite outcrops in the south and dips to the north, with roof collapse occurring in eastwest lines (Kuman 1994b). The karsts developed through the intermittently falling water table, which leached calcium carbonate from the dolomitic bedrock (Butterick et al. 1993; Wilkinson 1983). Speleological survey of Sterkfontein undertaken by Martini et al. (2004) confirms the cave systems formed from a single speleogenetic event, with cavity infills introduced through a pit entrance, mainly in the vadose setting (above the water table), whereas surrounding phreatic passages (situated below the water table) were only partially filled or were left open. Further leaching formed joint-determined cavities, passage networks and wall pockets in the phreatic zone, which were subsequently enlarged through cave-ins above the water table. As a result of the developing karst landscape the surface became unstable in areas with the production of narrow slots (or avens) and eroded surficial sections, allowing the influx of fragmented rocks, fauna, clays and other detrital material. The total exposure of the Sterkfontein caves is approximately $65 \times 35 \mathrm{~m}$ (Wilkinson 1983), and the opening of the Sterkfontein cave is convoluted, with large dolomite overhangs and treacherous secreted holes (Figure 3). More than 500 hominid-associated fossils have been recovered from the brecciated infills.

\section{Member 5: artefacts and residues}

Member 5 was formed between 2.8 and 1.5 million years ago (Partridge and Watt 1991). Kuman and Clarke (2000:827) describe the paleoenvironment for M5 as representing more open woodland and grassland than M4, however the Oldowan infill in the eastern section of M5 suggests a wet localised paleoclimate. The member comprises a pinkish to reddish-brown, well calcified breccia with abundant rock debris, which was replaced by an orange, sandy breccia during periods of collapse, erosion and infilling (Clarke 1994; Partridge and Watt 1991) (Figure 4).

Evidence of Australopithecus and Homo species, early Pleistocene fauna and archaeological artefacts (totalling 9000 pieces ranging from Oldowan to Early Acheulean technologies; Kuman 1994a) have been found within this deposit. The tools found in M5 include chopper-like cores, discoid cores, and protobifaces (Figure 5). All flakes are smaller than $10 \mathrm{~cm}$, have limited retouch, and lack variety throughout the assemblage (Kuman 1994b). The Oldowan industry comprises 2800 tools dated to 1.7-2.0 million years on the basis of associated fossils. The Oldowan assemblage associated with M5 is the first systematic evidence for hominid tool use in South Africa, and 
Selected sites

- Australopithecus afarensis

- Homo habilis

Australopithecus africanus
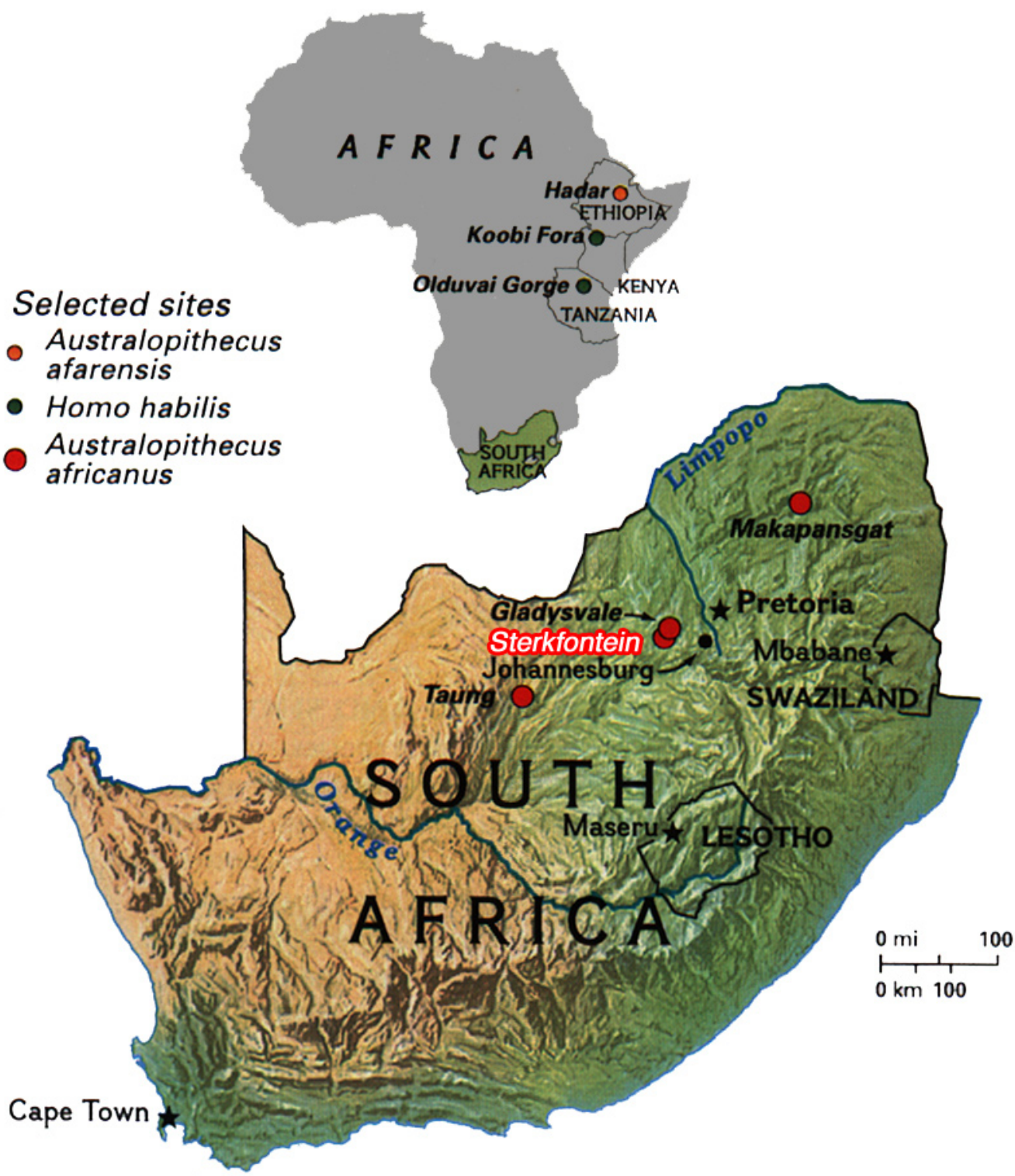

Figure 2. Location map of Sterkfontein, Swartkrans, Kromdraai, and other archaeologically significant sites (after Gauteng Department of Agriculture, Conservation and Environment South Africa: 1998).

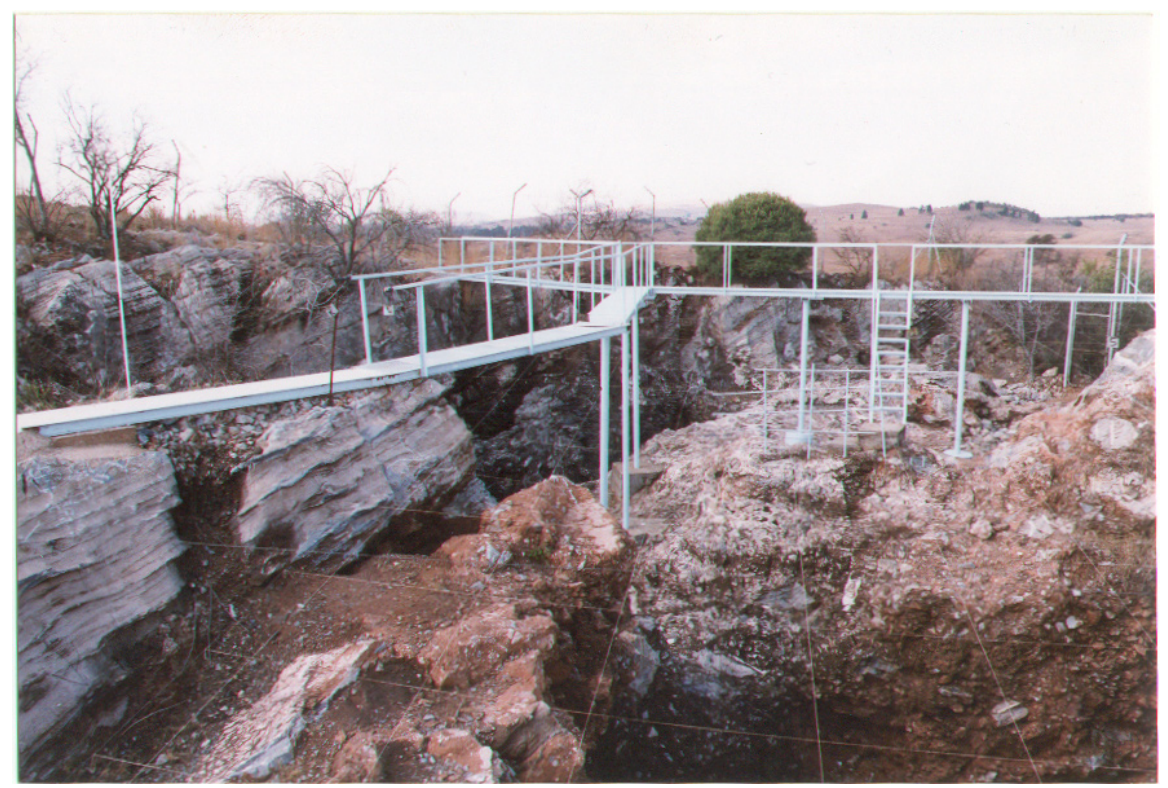

Figure 3. Surficial exposure of Sterkfontein. 


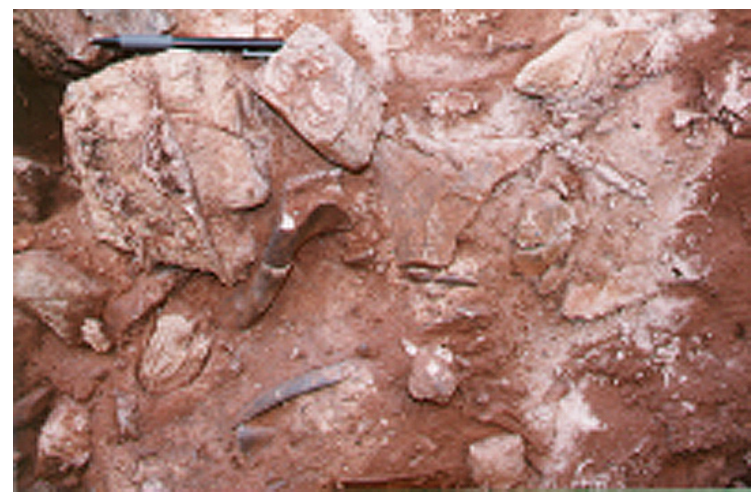

Figure 4. Orange, sandy debris-rich breccia, comprising Sterkfontein M5 (pencil is $13 \mathrm{~cm}$ long).

M5 has been interpreted as representing the first major hominid occupation of caves in the Sterkfontein Valley (Vrba 1980:270)

Loy (1998) analysed residues on 35 stone tools from M5. Of these tools, $43 \%$ had animal residues and $17 \%$ had plant residues; the rest contained a mixture of both. A bird feather (possibly of the Falconiform order), starch grains, plant fibres, wood, cells and collagen were observed. Other residues included anucleate circular red blood cells (5-8 $\mu \mathrm{m}$ in diameter), nucleated cells, proteinaceous films mixed with clay (Figure 6), degraded and fragmented hairs, feather barbule fragments, collagen fibrils, collagen sheets and collagen powder. Of the residues found by Loy, those applicable to this study are blood proteins.

\section{MICROSTRATIGRAPHIC ANALYSIS}

The microstratigraphic analysis for this study involved petrography, $\mathrm{pH}$ determination and cation exchange capacity (CEC) experimentation to investigate factors contributing to residue preservation. Petrographic and $\mathrm{pH}$ analyses were used to understand the composition of the matrix surrounding the residues, and the CEC experiments indicated how readily the surrounding matrix would exchange cations. The geological samples used in this study were Sterkfontein dolomitic bedrock and breccia from the Oldowan Infill of M5. Dolomite is a chemical sedimentary rock that develops in situ whereas breccia is a clastic sedimentary rock formed from cemented rock fragments.

\section{Petrography}

The petrographic analysis involved microstratigraphic study of thin and polished sections, including the shape, form and colour of individual minerals, crystals, and grains, from which the depositional history of a rock can be inferred (Berry and Mason 1959; Kerr 1959). The optical mineralogy of each section was studied and distinguishing features such as colour, pleochroism, birefringence, cleavage, twinning, extinction, relief, crystal form and alteration were noted. Analysis points were taken at random coordinates from areas of general interest. To determine rock volume percentages, 4500 coordinates were observed on each of the thin and polished sections, with the variables at each coordinate entered into a database.

Bloombaum's (1970) 'mapping sentence analysis', adapted by Loy (1972), was used to classify the information in the petrographic database. Observed petrographic attributes were used to build unique 'facets', which consisted of an accumulation of diagnostic traits for each unidentified constituent. Standard definitions were also formulated into facets for comparative purposes (Berry and Mason 1959; Ehlers 1987). Crystals were identified by comparing the breccia and dolomite constituents with these 'ideal' text-book facets. Mineral crystals rarely display the perfect features demonstrated in text-book examples because perfect crystal forms seldom occur under natural conditions (Watson 1972). Using facets as a categorical tool enables relationships between variables to be recognised and analysed, leading to the identification of constituents. Patterns identified included alteration to clay, rock volume percentage and structure.

\section{$p H$}

$\mathrm{pH}$ (a symbol for hydrogen-ion concentration) is a measure of the acidity or alkalinity of a solution. The method for soil $\mathrm{pH}$ determination used in this study was taken from Cope and Evans (1985). Two gram fragments from each of the breccia and dolomite samples (broken up 


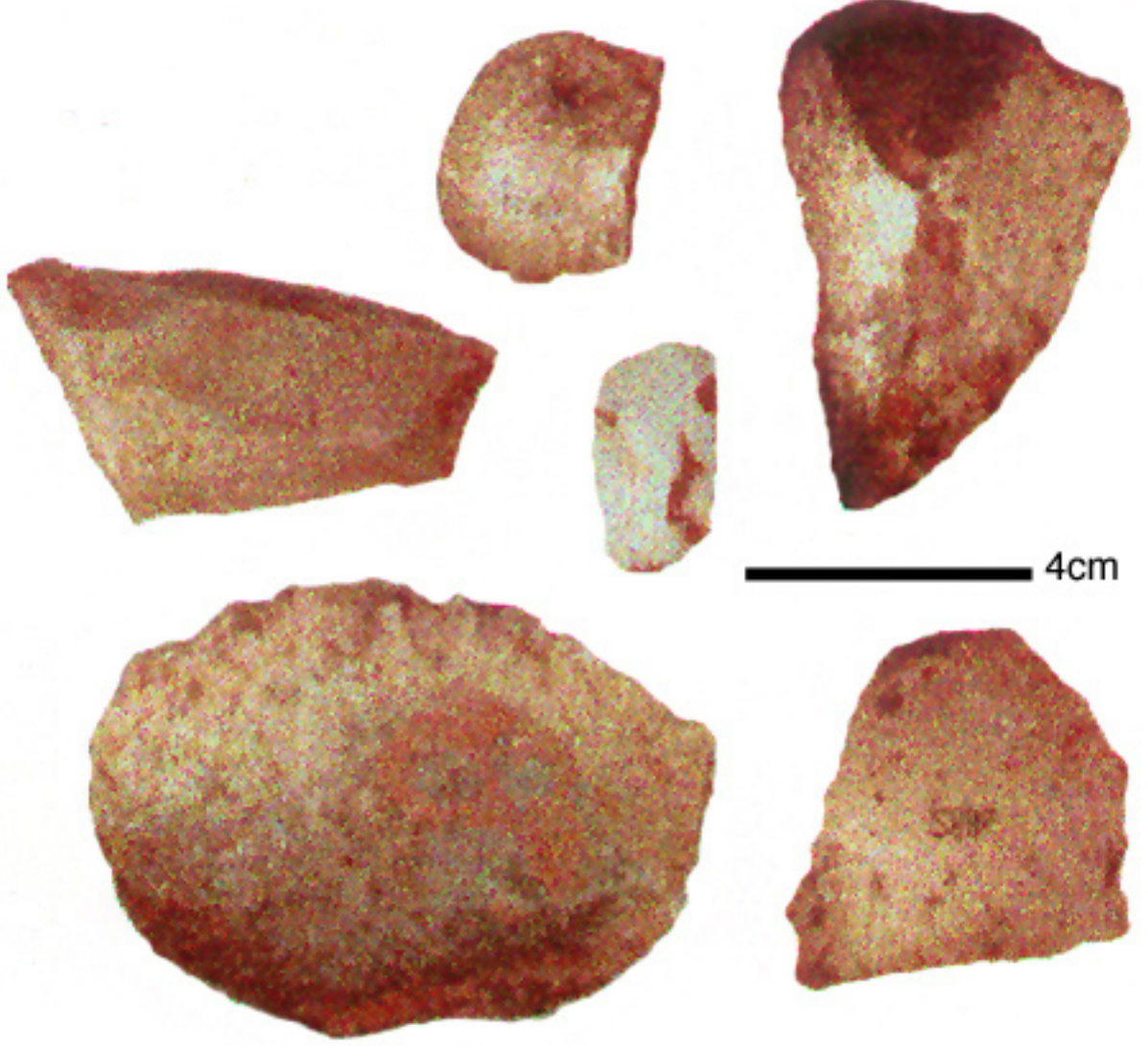

Figure 5. Oldowan stone tools recovered from Sterkfontein M5.

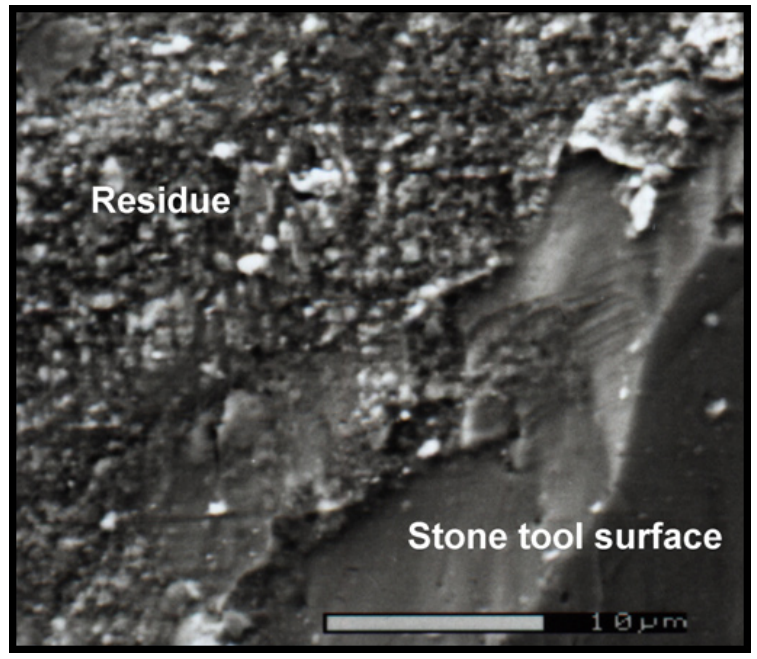

Figure 6. SEM micrograph of proteinaceous residue film mixed with clay found on Oldowan stone tool no. StK3312 (scale bar $=10 \mu \mathrm{m}$; micrograph and interpretation courtesy of Tom Loy). as a result of section production and the $\mathrm{CEC}$ experiment) were ground to a coarse powder with a mortar and pestle. Milli-Q water was used to mix the ground samples. Before the samples were added, the $\mathrm{pH}$ of the water was calibrated using an electronic $\mathrm{pH}$ meter. The $\mathrm{pH}$ of the samples mixed into the water was then subtracted from the $\mathrm{pH}$ of the water to determine the breccia and dolomite $\mathrm{pH}$ values.

\section{Cation exchange capacity}

This study describes the first use of cation exchange capacity (CEC) field work to investigate the preservation of ancientresidues (Jones 1998). Orlov (1992) described cation exchange as a reversible chemical reaction and the CEC of a material as the sum of exchangeable cations it contains. Soil matrices possess an exchange complex comprising

various cations, including $\mathrm{Ca}^{2+}, \mathrm{Mg}^{2+}, \mathrm{K}^{+}$, and $\mathrm{Na}^{+}$, and these exchangeable cations are attracted by negative charges (Marshall et al. 1996). The capacity for cations to be exchanged varies with the type of clay, crystal size, isomorphous substitution and $\mathrm{pH}$ (Marshall et al. 1996).

This study used a simplified methylene blue method for rapid determination of CEC in the field (Savant 1993). The determination of CEC is defined as milligram-equivalents (me.) in $100 \mathrm{~g}$ of soil, and the range of exchange capacity is from $<1.0$ to $>100 \mathrm{me} . / 100 \mathrm{~g}$. Two of the geological 
samples (one breccia and one dolomite) were ground to a fine powder using a mortar and pestle. Two grams of each ground sample were measured using electronic scales. Each amount was then transferred to $250 \mathrm{ml}$ capacity Erlenmeyer flasks, and $50 \mathrm{ml}$ of $1 \%$ sodium carbonate solution $\left(\mathrm{Na}_{2} \mathrm{CO}_{3}\right)$ were added to each. After 10-15 minutes of shaking, the suspensions were titrated: $1 \mathrm{ml}$ of $0.01 \mathrm{M}$ methylene blue solution was released into the $\mathrm{Na}_{2} \mathrm{CO}_{3}$ suspension. The sample was then gently swirled by hand for 60 seconds. A glass rod was dipped into the solution and then dot-blotted onto Whatman No. 1 filter paper.

Observations were recorded and then the flask was placed under a burette where $1 \mathrm{ml}$ methylene blue solution was released again. The procedure was continued until a halo could be observed around the deposited solution. The volume of methylene blue required to create a halo was multiplied by a constant (0.535) to determine a number that was ascribed a CEC value.

\section{RESULTS}

\section{Petrography}

The results of the facet analyses of the thin sections showed that the breccia samples had seven components (Figure 7). These components with their relative proportions were: calcite (49\%); clay $(38 \%)$; dolomite $(7 \%)$; quartz $(5 \%)$; and chlorite, biotite, and bone (together totalling approximately $1 \%$ ). The key elements were calcite and clays.

Variations in crystal structure of the breccia samples showed that both anhedral and euhedral crystal growths occurred in the calcite (Figure 8). Approximately $91 \%$ of the calcite groups displayed anhedral crystals and $51 \%$ of the calcite groups displayed euhedral crystal types. Rhombohedral crystal morphology was apparent on $85 \%$ of the calcite studied and was attributed to both anhedral and euhedral crystal types. The euhedral crystal types surround air-filled voids and were large compared to the anhedral crystals. The anhedral crystals formed a flow-like distribution.

The breccia contained a high proportion (38\%) of clay minerals. The clay crystal type was massive with no identifiable structure. There was no deviation from this form; it comprised $100 \%$ of the observed clay's structure. Chlorite, biotite, bone fragments and dolomite were the minerals displaying the greatest amount of clay formation. Quartz also had some clay-forming crystals; however, quartz is a strong, dense mineral that does not break down as easily as other minerals (Hamblin 1992).

The dolomite rock comprised clasts within the breccia and was formed from dolomite, calcium, magnesium and trace amounts of manganiferous minerals. The dolomite in the breccia sections displayed the largest variation in structure but was of no real consequence to this study because the dolomite formed before the archaeological deposits. The total amount of anhedral crystal morphology of the observed quartz grains was $100 \%$, whereas chlorite displayed $87.5 \%$ lathlike crystal structure. The amount of mineral biotite observed was $100 \%$ lathlike in structure, with $10 \%$ of the crystals held within the boundaries of the bone structures also displaying lathlike morphology.

The breccia constituents were considered immature because they were not well rounded or well sorted. The very poor sorting, massive fabric, fine to medium size and subangular roundness of the breccia grains (Figure 9) is indicative of the depositional environment. The breccia was initially deposited in a high-energy environment, as is evident in the extremely coarse nature of the clasts (larger clasts require more depositional energy). The modifying energy was low, as reflected in the angularity and sorting of the breccia grains. This interpretation is consistent with the palaeoenvironmental reconstructions of Scott and Partridge (1994), whose research into manifestations of Pliocene warming in southern Africa showed that episodic sheetfloods were responsible for the shift from fine clastic sediments to coarser colluvial sediments. 
Total Rock Volume Percentages for M5 Breccia

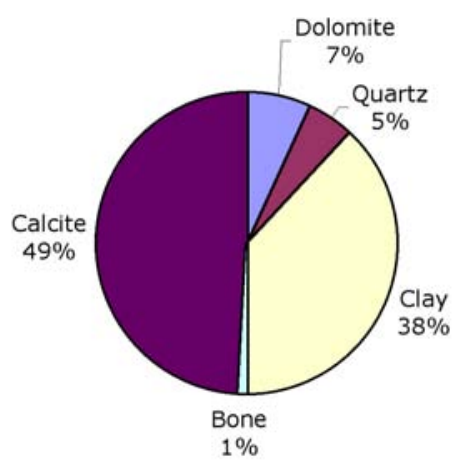

Figure 7. Total rock volume percentages for breccia samples.
pH and cation exchange capacity

The $\mathrm{pH}$ results ranged from 8.34-9.86 for the dolomite and 8.34-10.38 for the breccia sample, indicating alkaline conditions. The cation exchange capacity analysis of the Sterkfontein samples produced ambiguous results. The initial halo (the determining factor) was faint so the next definite halo was also recorded to give a range of CEC values. This was not unexpected - results from Savant (1993) also gave a range of values. The $2 \mathrm{~g}$ of ground dolomite taken from the surface of the Sterkfontein site had a cation exchange capacity of $2-5 \%$. The $2 \mathrm{~g}$ of ground breccia taken from M5 of the Sterkfontein site displayed a cation exchange capacity of $15-40 \%$.

\section{DISCUSSION}

This investigation has identified clay and calcite as the major constituents of the breccia matrix surrounding the M5 Oldowan stone tools, with a relatively high $\mathrm{pH}$. The CEC results show the calcite samples to have a higher exchange capacity than the dolomite. As discussed below, these findings are broadly supportive of the potential for long-term blood residue survival at Sterkfontein as claimed by Loy (1998) and are further enhanced by the cave setting. Compared to open-air sites, rockshelters and caves are considered major contributors to influencing the preservation of archaeological material, particularly if stone tools are buried quickly (Tuross et al. 1996; Ward et al. 2006; Heydari 2007). In addition Kimura et al. (2001) suggest that tools protected from the outside environment, for example in caves and similar structures, would have an increased chance of preserving analysable DNA.

\section{Clay and minor constituents}

The petrographic examination of the M5 samples found clay and calcite to be the major constituents, with other minerals and fossilised bone also observed in minor amounts. Intermittently wet conditions are ideal for clay formation, because water accelerates the chemical breakdown of rock minerals to clays. Therefore, the high clay content (and the $\mathrm{pH}$ values) of the M5 deposits indicate a well-watered environment at the time that the stone tools containing residues were buried. However, the degree of clay formation in the breccia minerals is not significant enough to account for the high clay content recorded. Therefore, it is suggested that the majority of the clays were introduced into the system through primary deposition. The nearby river and the Malmani dolomite may have been a major source of the other breccia minerals. The clay and a proportion of the less abundant breccia minerals were likely introduced into the cave deposits through fluid dynamics and rockfall. The more distantly transported constituents, including quartz, chlorite and biotite, would have entered the cave via rain, floods or rock fall as a result of disturbances at the cave's entrances.

The bone found in the breccia may have been deposited in a similar manner to the quartz, chlorite and biotite; through gravitation and sheet flooding. An additional factor that may have contributed to bone deposition is hominid interaction. The Sterkfontein caves may have been used as a disposal centre for the deceased; unsuspecting hominids may have stumbled and fallen into the treacherous caves; or predators may have dropped bones from over hanging trees, such as with the myriad of small bones found in the breccia thin sections that likely represent the remains of an owl's prey, including tiny lizards or mice (Brain et al. 1988). The Sterkfontein Oldowan tools 


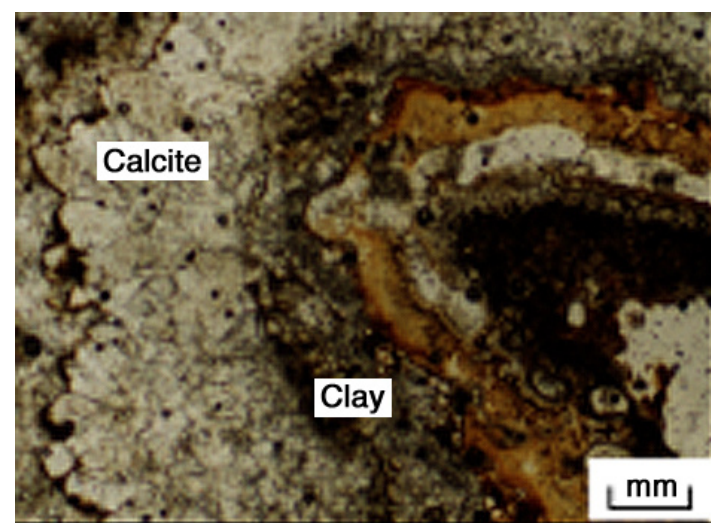

Figure 9. Photograph of M5 breccia showing poor sorting, massive fabric and subangular grains, indicative of a highenergy depositional environment.

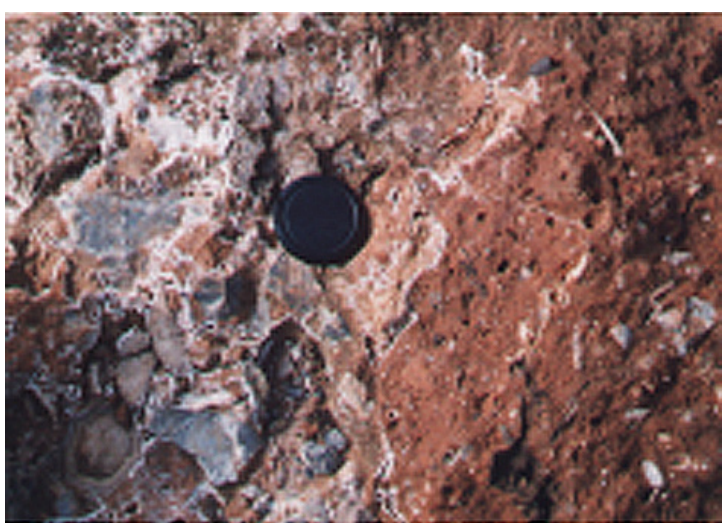

Figure 8. Micrograph of calcite crystals tightly packed around breccia minerals of Sterkfontein's M5 deposit (scale in mm).

would have entered the site in a similar manner to the bones, for example, as part of surface debris dropping in, or through hominid use of the cave for shelter and food procurement.

Upon burial, the clay would have come into contact with any blood residues. Pinck and Allison's (1951) investigations describe the preservation of proteins bound to clay, and Gurfinkel and Franklin (1988) suggest that blood binds to soil and clay (see also Loy 1983; Vettori et al. 1996). Clay complexes have been reported to protect bound DNA (including proteinaceous constituents) (Alvarez et al. 1998; Crecchio and Stotzky 1998; Gallori et al. 1994; Stotzky 1986). Residual blood molecules on a stone tool have a highly reactive surface that contains a large number of positive and negative charges, which bind to ionic clay. The ionic bonding creates a linkage formed by the transfer of electrons from one atom (residue) to another atom (clay). Features to be considered in this exchange include cation size and valence, also known as the polarizing power; calcium cations are strongly polarizing (Oades 1989). The nature of the bonds can make recovering proteinaceous residues from ancient mineral surfaces extremely difficult (Craig and Collins 2000).

As organic material and clay minerals create persistent bonds, this suggests that clays bound to proteins (adsorbed) may act as a shield protecting archaeological proteinaceous blood residues from the detrimental effects of fluids, either ground water or surficial water (Jones 1998). The large surface area of some clay species allows for water to be adsorbed, swelling the clay structure and forming a diffuse layer of exchangeable cations extending out from the negatively charged surface to which reactive blood surfaces bind (Loy 1987). Cross-linking of covalent bonds between protein molecules may produce a mass of proteins through aggregation. The resultant organic-bonded materials act as a shield protecting the residues from the detrimental effects of diagenesis through microbial attack and water washing (Gurfinkel and Franklin 1988).

\section{Calcite}

The second major constituent of the M5 breccia was calcite. The potential importance to residue longevity of a cemented stable matrix developed through calcite precipitation has not previously been considered, although Thackeray (1997) reported the Sts 5 (Mrs Ples) fragments excavated from M5 were covered by a thin veneer of calcite, which would have formed prior to the cranial bone being buried in sediment.

Calcite has cemented the M5 cave deposits containing the stone tools, clasts, and clay. The calcite content of the breccia displayed two structural morphologies: anhedral crystals, which were small, amorphous crystals in a flow-like distribution, and euhedral crystals, which were more evenly shaped, with larger, well-formed crystals. The majority of the euhedral crystals were distributed in circular patches surrounding an air-filled void. These two crystal morphologies most likely indicate two phases of calcification (Jones 1998). The flow-like distribution of the small 
anhedral calcite crystals indicates a period of rapid deposition in an area of little space for growth. The euhedral or equant calcite growths surrounding air-filled voids may have formed after the unconsolidated breccia was cemented by the first calcite deposition (James and Choquette 1988; Moore 1989).

Analysis of the site suggests that the two phases of calcification were the result of either a climatic event (Jones 1998) or water table variation. The anhedral calcite may have been associated with increased water flux producing a significant amount of calcite in solution that was deposited rapidly as small, amorphous crystals. The second phase of calcification could then have occurred over a longer period of time, during which there was relatively little rainfall with smaller amounts of calcite solution released at any one time. This environment would have allowed gradual growth of large, well-formed crystals. An alternative explanation may be that the anhedral crystals grew in the phreatic zone and the well-formed euhedral crystals grew in the vadose zone. The use of staining procedures to determine which cementation took place first (Scholle et al. 1989) would be a worthwhile avenue of future research.

It is suggested here that calcite plays a role in the preservation mechanics of proteinaceous archaeological residues. The CEC experiment found that the M5 breccia had a higher capacity to exchange cations than the dolomite. The relatively high CEC value of the breccia could be attributed to the presence of the calcite, which possesses a large amount of cations with high mobility (Press and Siever 1986). These exchangeable cations are available in solution and are attracted to the negatively charged surface of the clay, creating a weak ionic bond (Press and Siever 1986). Calcium is a divalent cation with a higher charge and is therefore more strongly attracted to the clay surface then other free cations (Marshall et al. 1996).

Mitterer and Cunningham (1985:17) state that organic material interacts with calcium carbonate systems in two ways: (i) adsorption of the organic material to calcium carbonate surfaces, and (ii) complexation or chelation of free cations by dissolved or adsorbed organic material. If clay bonds to blood residues and calcite bonds weakly to clay, a protective shield for the blood residues may result. Furthermore the crystallised form of calcite can help protect the clay and blood from degradative processes through the tight packing of crystals and continual growth from solution and further sequestration of the proteins away from the active soil environment (Jones 1998). Upon lithification the clay and calcite are cemented together and the clay sediment dries, which would sequester water away within clay minerals. These clay minerals are capable of extracting and absorbing water from most other materials. Dried clay sediments are strong and stable, particularly with the dominant presence of the alkaline clay mineral montmorillonite. The calcification of the M5 deposits therefore cemented the immediate environment of the blood-clay bond and further protected them from detrimental processes.

\section{Other Sites}

The reported detection of two million year old blood residues on Oldowan stone tools from Sterkfontein (Loy 1998) is supported by the taphonomic history of the site as recorded in the microstratigraphy. This study suggests that a cave environment and a well cemented, clay-rich burial matrix with an alkaline $\mathrm{pH}$ and high CEC favours residue preservation over extreme timeframes. This hypothesis can be indirectly tested by reviewing sites with similar and differing taphonomic contexts that both preserve and do not preserve proteinaceous residues.

Cave and rockshelter sites that have been found to preserve blood residues include the Enclosed Chamber of Rocky Cape South, Tasmania (Fullagar 2004) and La Quina, southwest France (Hardy et al. 1997). In these cases it is assumed that the physical barrier of the enclosed or covered sites was a critical contributing factor in residue preservation, as neither site has a significant clay component in the burial matrix. While the preservation timeframes are significantly less than at Sterkfontein (6,000 and 40,000-48,000 years old, respectively), if the site morphology persists through time then the preserving physical barrier will not be diminished, even over millions of years. 
Blood residues 30,000 to 36,000 years old have been discovered in clay-rich burial matrices in the Australian megafauna site of Cuddie Springs (Field et al. 2006; Garling 1998) and the wetland Monte Verde site in Chile (Tuross and Dillehay 1995). The Cuddie Springs and Monte Verde sites formed in low energy environments at the surface (i.e. not in a cave). The clay content of the burial matrix may have been the primary contributing factor in the preservation of the residues; however, the host stone tools were recovered beneath strata that may have provided a physical barrier to detrimental surficial processes (Cuddie Springs - compacted clay layer; Monte Verde peat layer rich in silica gel). These strata may have played a similar role to the lithifiying calcite in the Sterkfontein site.

Archaeological sites of comparable age and taphonomic history to Sterkfontein that do not preserve blood residues include the Peninj site in Tanzania and the Okote Member of the Koobi Fora Formation in East Africa. In Peninj, tools dated to 1.5 Ma have been recovered from consolidated sands and clays in a muddy sandstone matrix that include carbonates and calcite (Dominguez-Rodrigo et al. 2001). The site maintained a good preservation environment, but there is no evidence of animal processing activities. It is likely therefore that the absence of blood residues is a function of tool use rather than non-preservation. The geology of the upper part of the surficial Koobi Fora site is defined as a caliche (calcium carbonate block) with sands, gravels, sandy silt with calcareous concretions, and volcanic tuff comprising the other layers (Rogers and Harris 1992:43). Hardy and Rogers (2001) report the detection of residues on stone tools dated to 1.5-1.6 Ma. These residues included woody and non-woody plant tissue, starch grains, and hair fragments. Hardy and Rogers (2001) indicate that the Okote artefacts were used to process plant and animals, which is consistent with cutmarks found on bone from the site (Bunn 1981). These tool use reconstructions suggest that in the case of the Koobi Fora site, the absence of blood residues on the stone tools is due to non-preservation despite the presence of clay in the lithified burial matrix.

A brief review of international case studies therefore supports some of the key findings from this study. The detection of proteinaceous archaeological residues between 6,000 and 48,000 years old in Australia, Chile and France is due to varying combinations of clay fraction in the burial matrix, the sealing of archaeological deposits through lithification or a similar process, and the protected environment of cave systems and rockshelters. The absence of blood residues from stone tools used to process animals in the lithified, calcareous and partly silty burial matrix of the Koobi Fora site in East Africa suggests that the physical barrier of a cave system may be the primary requisite factor in the possible preservation of proteinaceous residues for millions of years, as in the Sterkfontein site. However, this is likely to be an over-simplification, with the potential for the preservation of blood residues for greater than two million years likely requiring a specific combination of the factors described in this study, and for these to have influenced the taphonomy of the site in a particular series of events.

\section{CONCLUSIONS}

From this investigation it can be stated that the burial matrix of the Oldowan infill from M5 has provided and maintained a stable and non-detrimental environment to archaeological remains, attested to by the exceptional preservation of hominid remains and the presence of a large number of stone artefacts. Significant factors in this context included both the burial matrix and the environmental setting (dolomitic karst caves that provided ingress points for the stone tools and covering sediments, and that may have attracted hominins in the first place). Loy's (1998) claim of blood residue preservation on M5 Oldowan tools, combined with the findings of this study, therefore suggests a specific scenario as follows:

1. Hominids use stone tools multiple times in the processing of animals which leaves behind a thick layer of blood residues; 
2. Blood dries onto the stone tool surface, residues are denatured and/or sequestered into microcracks;

3. Stone tools are transported, residues come into contact with clay;

4. Some degree of binding occurs which creates hydrophobic organic-protein complexes;

5. Archaeological remains and sediment are transported;

6. Deposition from entrances i.e. side of hills, avens or slopes;

7. Clay sediment provides a large surface area, swelling capability, diffuse layers of exchangeable cations and a negatively charged surface which all encourage organic-mineral complexes;

8. The aggregation of proteins with clay makes them more resistant to degradation;

9. Rainfall releases calcium ions from the overlying dolomitic bedrock (leaching);

10. The leached solution filters through the underlying gravity-derived sediments and precipitates as calcium carbonate (calcite) that subsequently cements the deposits into brecciated infill;

11. Calcium ions are adsorbed to organic material;

12. Weak bonds form between clay and calcite surfaces;

13.Precipitated calcite creates a well-cemented clay/calcite matrix enclosing and protecting the hominid-bearing deposits, including the blood residues;

14. The breccia matrix maintains a regulated environment that is not directly exposed to surficial water and was possibly buried with further compaction from overlying brecciated deposits, protected from detrimental conditions.

\section{ACKNOWLEDGEMENTS}

I am indebted to Meg Heaslop, Andrew Jones and Michael Haslam for their input into the various manuscripts that came their way. This study would not be possible without the aid of Ron Clarke, Kathy Kuman, and Francis Thackeray, who patiently showed me around the Sterkfontein region and dedicated their time to collecting rock samples. Thank you to Peter Colls whose geotechnical skills helped create the thin sections that were integral to this study. The comments offered by two reviewers were also greatly appreciated. Funds were supplied in part by an Australian Postgraduate Award. Thank you also to my mentor Dr T.H. Loy for having faith in me in the first place and for offering continual support, I miss you dearly.

\section{REFERENCES}

Alvarez, A.J., M. Khanna, G.A. Toranzos, and G. Stotzky 1998. Amplification of DNA bound on clay minerals. Molecular Ecology 7:775-778.

Berger, L. 1998. The dawn of humans: redrawing our human tree? National Geographic 198:9099.

Berry, L.G. and B. Mason 1959. Mineralogy: Concepts, Descriptions, Determinations. San Francisco: W. H. Freeman and Company.

Bloombaum, M. 1970. Doing Smallest Space Analysis. Journal of Conflict Resolution 14:409416.

Brain, C.K., C.S. Churcher, J.D. Clark, F.E. Grine, P. Shipman, R.L. Susman, A. Turner and V. Watson 1988. New evidence of early hominids, their culture and environment from the Swartkrans cave, South Africa. South African Journal of Science 84:828-835.

Briuer, F.L. 1976. New clues to stone tool function: plant and animal residues. American Antiquity 41:478-484. 
Brown, P. 1988. Residue analysis of stone artefacts from Yambon, West New Britain. Unpublished BA (Honours) thesis. Sydney: University of Sydney.

Bunn, H.T. 1981. Archaeological evidence for meat-eating by Plio-Pleistocene hominids from Koobi Fora and Olduvai Gorge. Nature 291:574-577.

Butterick, D.B., J.L. van Rooy, J.L. and R. Ligthelm, R. (1993). Environmental geological aspects of the dolomites of South Africa. Journal of African Earth Sciences 16:53-61.

Cattaneo C., K. Gelsthorpe, P. Phillips and R.K. Sokol 1990. Blood in ancient human bone. Nature $347: 339$.

Cattaneo C., K. Gelsthorpe, P. Phillips and R.K. Sokol 1993. Blood residues on stone tools: indoor and outdoor experiments. World Archaeology 25:29-43.

Chafetz, H.S., B.H.Wilkinson and K.M. Love 1985. Morphology and composition of non-marine carbonate cements in near-surface settings. In N. Schneidermann and P.M. Harris (eds) Carbonate Cements (No. 36), pp. 337-347. Oklahoma: Society of Economic Paleontologists and Mineralogists.

Clarke, R.J. 1994. On some new interpretations of Sterkfontein stratigraphy. South African Journal of Science 90:211-214.

Cope, J.T. and C.E. Evans 1985. Soil Testing. Advances in Soil Science 1:201-228.

Craig, O.E. and M.J. Collins 2000. An improved method for the immunological detection of mineral bound protein using hydrofluoric acid and direct capture. Journal of Immunological Methods in Enzymology 236:89-97.

Crecchio, C. and G. Stotzky 1998. Binding of DNA on humic acids: effect on transformation of Bacillus subtilis and resistance to DNase. Soil Biology and Biochemistry 30:1061-1067.

Dashman, T. and G. Stotzky 1982. Adsorption and binding of amino acids on momoinic montmorillonite and kaolinite. Soil Biology and Biochemistry 14:447-456.

Dominguez-Rodrigo, M., J. Serralonga, J. Juan-Tresserras, L. Alcala and L. Luque 2001. Woodworking activities by early humans: a plant residue analysis on Acheulian stone tools from Peninj (Tanzania). Journal of Human Evolution 40:289-299.

Ehlers, E.G. 1987. Optical mineralogy Vol. 2. London: Blackwell Scientific Publications.

Eisele, J.A., D.D.Fowler, G. Haynes and R.A. Lewis 1995. Survival and detection of blood residues on stone tools. Antiquity 69:36-46.

Enloe, J.G. 2006. Geological processes and site structure: Assessing integrity at a Late Paleolithic open-air site in northern France. Geoarchaeology 21:523-540.

Field, J., S. Wroe and R. Fullager 2006. Blitzkrieg: fact and fiction at Cuddie Springs. Australasian Science 27:28-29.

Fullagar, R. 2006. Residues and usewear. In J. Blame and A. Paterson (eds) Archaeology in Practice: A student guide to archaeological analysis, pp. 207-234. Malden: Blackwell Publishing.

Fullagar, R. and J. Field 1997. Pleistocene seed-grinding implements from the Australian arid zone. Antiquity 71:300-307.

Fullagar, R.J. and R. Jones 2004. Usewear and residue analysis of stone artefacts from the Enclosed Chamber, Rocky Cape, Tasmania. Archaeology in Oceania 39:79-93. 
Fullagar, R., J. Furby and B. Hardy 1996. Residues on stone artifacts: state of a scientific art. Antiquity 70:74-745.

Fullagar, R.J., J. Field, T. Denham and C. Lentfer 2006. Early and mid Holocene tool use and processing of taro (Colocasia esculenta), yam (Dioscorea sp.) and other plants at Kuk Swamp in the highlands of Papua New Guinea. Journal of Archaeological Science 33:595614.

Gallori, E., M. Bazzicalupo, L. Dal Canto, R. Fani, P. Nannipieri, C. Vettori, and G. Stotzky 1994. Transformation of Bacillus subtilis by DNA bound on clay in non-sterile soil. Federation of European Microbiological Societies Microbiology Ecology 15:119-126.

Garling, S.J. 1998. Megafauna on the menu? Haemoglobin crystallization of blood residues from stone artefacts at Cuddie Springs. In R. Fullagar (ed.) A Closer Look, pp. 29-48. Sydney: Sydney University.

Gerlach, S.C., M. Newman and E.J. Knell Jr. 1996. Blood protein residues on lithic artifacts from two archaeological sites in the De Long Mountains, northwestern Alaska. Arctic 49:1-10.

Grimshaw, R.W. 1971. The Chemistry and Physics of Clays and Allied Ceramic Materials. London: Ernest Benn Limited.

Gurfinkel, D.M. and U.M. Franklin 1988. A study of the feasibility of detecting blood residue on artifacts. Journal of Archaeological Science 15:83-97.

Hamblin, W.K. 1992. Earth's Dynamic Systems (6th ed). New York: Macmillan Publishing Company.

Hanson, C.B. 1980. Fluvial taphonomic processes: models and experiments. In A.K. Behrensmeyer and A.P. Hill (eds) Fossils in the Making: Vertebrate taphonomy and paleoecology, pp. 156-181. Chicago: University of Chicago Press.

Hardy, B.L. 2004. Neanderthal behaviour and stone tool function at the Middle Palaeolithic site of La Quina, France. Antiquity 78:547-565.

Hardy, B.L., and M.J. Rogers 2001. Microscopic investigation of stone tool function from Okote Member sites, Koobi Fora, Kenya [abstract]. Journal of Human Evolution 40:A9.

Hardy, B.L., V. Raman and R.A. Raff 1997. Recovery of mammalian DNA from Middle Palaeolithic stone tools. Journal of Archaeological Science 24:601-611.

Harter, R.D. and G. Stotzky 1971. Formation of clay-protein complexes. Soil Science Society of America Proceedings 35:383-389.

Haslam, M. 2003. Evidence for maize processing on 2000-year-old obsidian artefacts from Copan, Honduras. In D. M. Hart and L. A. Wallis (eds) Phytolith and Starch Research in the Australian-Pacific-Asian regions: The state of the art, pp. 153-161. Canberra: Pandanus Books.

Haslam, M. 2004. The decomposition of starch grains in soils: implications for archaeological residue analyses. Journal of Archaeological Science 31:1715-1734.

Heydari, S. 2007. The impact of geology and geomorphology on cave and rockshelter archaeological site formation, preservation, and distribution in the Zagros mountains of Iran. Geoarchaeology 22:653-669.

Hiscock, P. 1985. The need for a taphonomic perspective in stone artefact analysis. Queensland Archaeological Research 2:82-95. 
Hortolà, P. 1992. SEM characterization of blood stains on stone tools. The Microscope 40:111113.

Hortolà, P. 2002. Red blood cell haemotaphonomy of experimental human bloodstains on technoprehistoric lithic raw materials. Journal of Archaeological Science 29:733-739.

Hyland, D., J. Tersak, J. Adovasio and M. Siegel 1990. Identification of the species of origin of residual blood on lithic material. American Antiquity 55:104-112.

James, N. P. and P.W. Choquette 1988. Introduction. In N.P. James and P.W. Choquette (eds) Paleokarst, pp. 1-21. New York: Springer-Verlag.

Jones, P. 1998. A Microstratigraphic Investigation into the Longevity of Archaeological Blood Residues, Sterkfontein, South Africa, Unpublished BA (Honours) thesis. St Lucia: Department of Anthropology and Sociology, The University of Queensland.

Kerr, P.F. 1959. Optical Mineralogy. 3rd ed. New York: McGraw-Hill Book Company.

Kimura, B., S.Brandt, B. Hardy and W. Hauswirth 2001. Analysis of DNA from ethnoarchaeological stone scrapers. Journal of Archaeological Science 28:45-53.

Kooyman, B., M.E. Newman and H. Ceri 1992. Verifying the reliability of blood residue analysis on archaeological tools. Journal of Archaeological Science 19:265-269.

Kuman, K. 1994a. The archaeology of Sterkfontein — past and present. Journal of Human Evolution 27:471-495.

Kuman, K. 1994b. The archaeology of Sterkfontein: preliminary findings on site formation and cultural change. South African Journal of Science 90:215-219.

Kuman, K. and R.J. Clarke 2000. Stratigraphy, artefact industries and hominid associations for Sterkfontein, Member 5. Journal of Human Evolution 38:827-847.

Latham, A.G. and. A.I.R. Herries 2004. The formation and sedimentary infilling of the cave of hearths and historic cave complex, Makapansgat, South Africa. Geoarchaeology 19:323342.

Loy, T.H. 1972. Archaeological Survey of Yoho National Park: 1971. Report submitted to Department of Indian and Northern Affairs: National Historic Parks and Sites Branch.

Loy, T.H. 1983. Prehistoric blood residues: detection on tool surfaces and identification of species of origin. Science 220:1269-1270.

Loy, T.H. 1987. Recent advances in residue analysis. In W. Ambrose and J. M. J. Mummery (eds) Archaeometry: Further Australasian Studies, pp. 57-65. Australian National University, Canberra.

Loy, T.H. 1998. Organic residues on Oldowan tools from Sterkfontein Cave, South Africa [abstract]. In H.S.M.A. Raath, K.L.K.D. Barkhan and P.V. Tobias (eds) Dual Congress of the International Association for the Study of Human Paleontology, and International Association of Human Biologists, pp. 74-75, Johannesburg: Department of Anatomical Sciences, University of the Witswatersrand Medical School.

Loy, T.H. and E.J. Dixon 1998. Blood residues on fluted points from eastern Beringia. American Antiquity 63:21-46.

Loy, T.H. and B.L. Hardy 1992. Blood residue analysis of 90000 year old stone tools from Tabun Cave, Israel. Antiquity 66:24-35. 
Marshall, T.J., J.W. Holmes and C.W. Rose 1996. Soil Physics. 3rd ed. Cambridge: Cambridge University Press.

Martini, J.E.J., P.E.Wipplinger, H.F.G. Moen and A. Keyser 2004. Contribution to the speleology of Sterkfontein Cave, Gauteng province, South Africa. Speleogenesis and Evolution of Karst Aquifers 2:1-20.

Mitterer, R.M. and R.C. Cunningham Jr. 1985. The interaction of natural organic matter with grain surfaces: Implications for calcium carbonate precipitation. In N. Schneidermann and P.M. Harris (eds) Carbonate Cements (No.36), pp. 17-31. Oklahoma: Society of Economic Paleontologists and Mineralogists.

Moore, C.H. 1989. Carbonte Diagenesis and Porosity. New York: Elsevier Publishing Company.

Morin, E. 2006. Beyond stratigraphic noise: unraveling the evolution of stratified assemblages in faunalturbated sites. Geoarchaeology 21:541-565.

Newman, M. and P. Julig 1989. The identification of protein residues on lithic artifacts from a stratified boreal forest site. Canadian Journal of Archaeology 13:119-132.

Oades, J.M. 1989. An introduction to organic matter in mineral soils. In J. B. Dixon and S. B. Weed (eds) Minerals in soil environments. 2nd ed., pp. 1244. Wisconsin: Soil Science Society of America.

Orlov, D.S. 1992. Soil Chemistry. Rotterdam: A.A. Balkema.

Partridge, T.C. and I.B. Watt 1991. The stratigraphy of the Sterkfontein hominid deposit and its relationship to the underground cave system. Palaeontologia Africana 28:35-40.

Piló, L.B., A.S.Auler, W.A.Neves, X.Wang, H. Cheng, and R. Lawrence Edwards 2005. Geochronology, sediment provenance, and fossil emplacement at Sumidouro Cave, a classic Late Pleistocene/Early Holocene paleoanthropological site in Eastern Brazil. Geoarchaeology 20:751-764.

Pinck, L.A. and F.E. Allison 1951. Resistance of a protein montmorillonite complex to decomposition by soil microorganisms. Science 114:130-131.

Press, F. and R. Siever 1986. Earth. 4th ed. New York: W. H. Freeman and Company.

Richards, T. 1989. Initial results of a blood residue analysis of lithic artefacts from Thorpe Common rockshelter, South Yorkshire. In I. P. Brooks and P. Philips (eds) Breaking the stony silence: Papers from the Sheffield lithics conference 1988, pp. 73-90. British Series 123. Oxford: British Archaeological Reports.

Rick, T.C., J.M. Erlandson and R.L. Vellanoweth 2006. Taphonomy and site formation processes on California's Channel Islands. Geoarchaeology 21:567-589.

Rogers, M.J. and J.W.K. Harris 1992. Recent investigations in landscape archaeology at East Turkana. Nyame Akuma 38:41-47.

South African Committee for Stratigraphy (SACS) 1980. Stratigraphy of South Africa. Part 1: Lithostratigraphy of the Republic of South Africa, South West Africa/Namibia and the Republics of Bophuthatswana, Transkei and Venda Handbook 8. Pretoria: Department of Mineral and Energy Affairs. 
Savant, N.K. 1993 Simplified methylene blue method for rapid determination of cation exchange capacity of mineral soils. Communications in Soil Science and Plant Analysis 23:33573364.

Schiffer, M.B. 1996. Formation Processes of the Archaeological Record. Salt Lake City: University of Utah Press.

Scholle, P.A., N.P. James and J.F. Read (eds) 1989. Carbonate Sedimentology and Petrology. Vol 4. Washington: American Geophysical Union.

Scoffin, T. P. 1987. An Introduction to Carbonate Sediments and Rocks. New York: Chapman and Hall.

Scott, L. and T.C. Partridge 1994. Some manifestations of Pliocene warming in southern Africa. In R.S. Thompson (ed.) Pliocene Terrestrial Environments and Data/Model Comparisons. U.S. Geological Survey Open-File Report 94-23: 54-55.

Sensabaugh, G.F., A.C. Wilson and P.L. Kirk 1971a. Protein stability in preserved biological remains I. Survival of biologically active proteins in an 8-year-old sample of dried blood. International Journal of Biochemistry 2:545-557.

Sensabaugh, G.F., A.C. Wilson and P.L. Kirk 1971b. Protein stability in preserved biological remains II. Modification and aggregation of proteins in an 8-year-old sample of dried blood. International Journal of Biochemistry 2:558-568.

Shanks, O.C., R.Bonnichsen, A.T. Vella and W. Ream 2001. Recovery of protein and DNA trapped in stone tools microcracks. Journal of Archaeological Science 28:965-972.

Shanks, O.C., M. Kornfeld and D.D. Hawk 1999. Protein analysis of Bugas-Holding tools: new trends in immunological studies. Journal of Archaeological Science 26:1183-1191.

Shanks, O.C., L. Hodges, L. Tilley, M. Kornfeld, M.L. Larson and W. Ream 2005. DNA from ancient stone tools and bones excavated at Bugas-Holding, Wyoming. Journal of Archaeological Science 32:27-38.

Stotzky, G. 1986. Influence of soil mineral colloids on metabolic processes, growth, adhesion, and ecology of microbes and viruses. In P.M. Huang and M. Schnitzer (eds) Interactions of Soil Minerals with Natural Organics and Microbes, no.17. Madison: Soil Science Society of America.

Thackeray, J.F. 1997. Cranial bone of 'Mrs Ples'; fragments adhering to matrix. South African Journal of Science 93:169-170.

Tuross, N. and T.D. Dillehay 1995. The mechanism of organic preservation at Monte Verde, Chile, and one use of biomolecules in archaeological interpretation. Journal of Field Archaeology 22:97-110.

Tuross, N., I. Barnes and R. Potts 1996. Protein identification of blood residues on experimental stone tools. Journal of Archaeological Science 23:289-296.

Vettori, C., D.Paffetti, G. Pietramellara, G. Stotzky and E. Gallori 1996. Amplification of bacterial DNA bound on clay minerals by the random amplified polymorphic DNA(RAPD) technique. Federation of European Microbiological Societies Microbiology Ecology 20:251-260.

Vrba, E. S. 1975. Some evidence of chronology and palaeoecology of Sterkfontein, Swartkrans and Kromdraai from the fossil Bovidae. Nature 254:301-304. 
Vrba, E.S. 1980. The significance of bovid remains as indicators of environment and predation patterns. In A.K. Behrensmeyer and A.P. Hill (eds) Fossils in the Making: Vertebrate taphonomy and paleoecology, pp. 247-271. Chicago: University of Chicago Press.

Wadley, L., M. Lombard and B. Williamson 2004. The first residue analysis blind tests: results and lessons learnt. Journal of Archaeological Science 31:1491-1501.

Ward, I.A.K., R. Fullagar, T. Boer Mah, L.M. Head, P.S.C. Taçon and K. Mulvaney 2006. Comparison of sedimentation and occupation histories inside and outside rock shelters, Keep-River region, northwestern Australia. Geoarchaeology 21:1-27.

Watson, J. 1972. Rocks and Minerals. In J.A.G. Thomas (ed.) Introducing Geology: 4. Rocks and Minerals, pp. 65. London: George Allen and Unwin Limited.

Wilkinson, M.J. 1983. Geomorphic Perspectives on the Sterkfontein Australopithecine Breccias. Journal of Archaeological Science 10:515-529.

Williamson, B. 1997. Down the microscope and beyond: microscopy and molecular studies of stone tool residues and bone samples from Rose Cottage Cave. South African Journal of Science 93:458-464. 